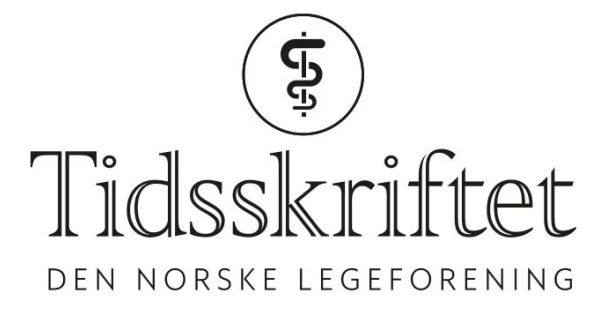

\title{
En tablett to ganger daglig mot koronavirus?
}

FRA ANDRE TIDSSKRIFTER

HAAKON B. BENESTAD

Universitetet i Oslo

Musestudier, og også humane studier, viser god effekt av peroral behandling mot flere typer koronavirus ved å hemme en virusspesifikk proteinase. 


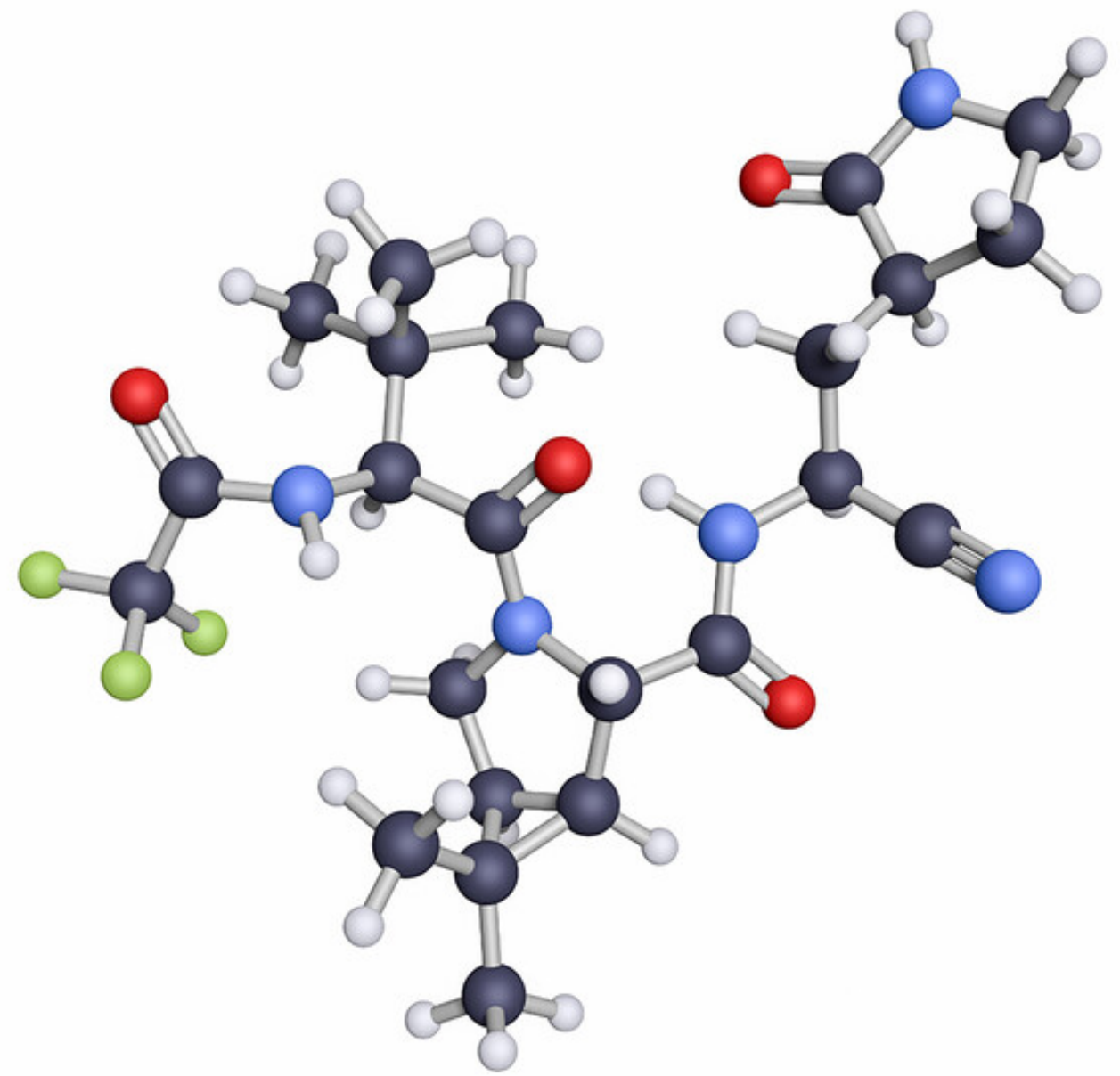

Nirmatrelvir. Illustrasjon: Science Photo Library / NTB

Koronavirus, som SARS-CoV-1-, MERS-CoV- og SARS-CoV-2-virus, har forårsaket flere farlige epidemier de siste 20 årene. Selv om SARS-CoV-2-vaksiner er effektive mot covid-19, dør mange uvaksinerte og pasienter som responderer dårlig på vaksinen. Mest frykter man at det skal oppstå nye virusmutanter som vaksiner ikke virker på.

Medikamenter som er godkjent mot andre sykdommer, kan tenkes å virke mot covid-19, særlig de som er virksomme mot viruskodete proteinaser, som f.eks. ved hivinfeksjon. Studier har imidlertid vist kun moderat effekt av slike midler.

I en ny studie ble et spesifikt virushemmende medikament tilpasset det aktive setet på den koronaspesifikke cysteinproteasen $\mathrm{M}^{\mathrm{pro}}(\underline{1})$. Denne proteasen kutter to viruspolyproteiner til en rekke mindre proteiner som trengs for virusreplikasjonen. I motsetning til humane cysteinproteaser kutter denne virusproteasen ved glutamin og kan dermed hemme virusspesifikt. Via flere modifikasjoner ble en prototype forbedret slik at medikamentet skulle virke ved lav konsentrasjon i virusinfiserte cellekolonier, ha godt enteralt opptak i forsøksdyr og en akseptabel farmakokinetikk, bedømt som motstand mot nedbrytning i humane levermikrosomer.

Den valgte varianten, kalt PF-o7321332, var effektiv i cellekulturer avledet fra humane bronkial- og lungealveoleceller. I en musemodell der koronavirusinfeksjon ga vekttap, ga den normal vekst og redusert virusformering i lungene. I bivirkningstester var det ingen hemming av humane proteaser og ingen uheldige effekter i andre analysesystemer. PF07321332-hemmeren ble oksidert av cytokromet CYP3A4. En fase 1-studie med friske personer viste betydelig $ø$ kt plasmakonsentrasjon ved kombinasjon med den registrerte $\mathrm{CYP}_{3} \mathrm{~A}_{4}$-hemmeren ritonavir. 
- Denne studien gir håp om en mulig peroral behandling med et slikt kombinasjonspreparat mot alle typer koronavirusinfeksjoner, og er et godt eksempel på hvor raskt legemiddelutvikling kan gå når alt ligger til rette for det, sier Finn Olav Levy. Han er professor ved Avdeling for farmakologi ved Universitetet i Oslo og Oslo universitetssykehus.

- Ved å kjenne molekylstrukturene til proteasene fra forskjellige koronavirus har man ved hjelp av molekylær tilpasning og legemiddelkjemi endret et molekyl som hemmer proteasen i SARS-1-viruset til å hemme proteasen i SARS-CoV-2-viruset på en effektiv måte og gitt det egenskaper som egner seg for peroral dosering i mennesker, forklarer Levy.

- Studien beskriver forskningen som ligger bak legemiddelet Paxlovid, som er et kombinasjonslegemiddel med nirmatrelvir, dvs. PF-07321332, og ritonavir. Midlet er blitt godkjent av legemiddelmyndighetene i USA og EU til nødbruk mot covid-19 hos voksne høyrisikopasienter som er tidlig i sykdomsforløpet, sier Levy.

\section{REFERENCES}

1. Owen DR, Allerton CMN, Anderson AS et al. An oral SARS-CoV-2 Mpro inhibitor clinical candidate for the treatment of COVID-19. Science 2021;374: 1586-93. [PubMed][CrossRef]

Publisert: 7. februar 2022. Tidsskr Nor Legeforen. DOI: 10.4045/tidsskr.22.0065

(C) Tidsskrift for Den norske legeforening 2023. Lastet ned fra tidsskriftet.no 26. april 2023. 